ADDIN, Volume 13, Number 1, February 2019

\title{
Pesantren Resistance to Modern Education System and It's Implication to Culture of Learning: a Study on Pesantren Al-Is'af Kalabaan, Guluk- guluk, Sumenep, Jawa Timur
}

\author{
Mohammad Muchlis Solichin \\ Sekolah Tinggi Agama Islam Negeri (STAIN) Pamekasan \\ muchlissolichin69@gmail.com
}

\section{Abstract}

Pesantren (Islamic boarding school) grew as traditional Islamic education institutions since the beginning of Islam arrival to Indonesia. The kiai in the traditional pesantren educated the student set of classical Islamic text books those organized by the method sorogan and bandongan. In the early $20^{\text {th }}$ century, pesantrens have got challenge with school education system that introduced by Dutch Colonial Government in the first 1900s. The challenge to pesantren also came from Muslim Reformist which also performed modern educational system in their schools and madrasah. Facing the challenge, most of pesantren modernized their educational system by performing schools and madrasah affiliated to the Indonesian government. There were only a few pesantrens those rejected the of modern educational system. Pesantren al-Is'af rejected the school education system and had ben keeping the sustainability of traditional education of Islamic knowledge teaching learning. The rejection brought about the effort of the pesantren in sthrengtening teaching learning classical Islamic textbook (kitab kuning) with sorogan and bandongan methods. Some of the text books had taugt the 
rule of santri learning. There were many rules, norms and belief that resulted the culture of learning in Pesantren.

Keywords: Rejection, Islamic Boarding School, The Modernization of Education, Culture of Learning.

\section{Abstrak}

PERLAWANAN PESANTREN TERHADAP SISTEM PENDIDIKAN MODERN DAN IMPLIKASINYA PADA BUDAYA BELAJAR: STUDI DI PONDOK PESANTREN AL-IS'AF KALABAAN, GULUK-GULUK, SUMENEP, $J A W A$ TIMUR. Pesantren tumbuh sebagai lembaga pendidikan Islam tradisional sejak awal kedatangan Islam ke Indonesia. Kiai di pesantren tradisional mendidik siswa menggunakan buku teks Islam klasik yang diselenggarakan dengan metode sorogan dan bandongan. Pada awal abad ke-20, pesantren mendapat tantangan dengan sistem pendidikan sekolah yang diperkenalkan oleh Pemerintah Kolonial Belanda pada 1900-an. Tantangan bagi pesantren juga datang dari Muslim reformis yang juga menjalankan sistem pendidikan modern di sekolah dan madrasah mereka. Menghadapi tantangan tersebut, sebagian besar pesantren memodernisasi sistem pendidikan mereka dengan menyelenggarakan sekolah dan madrasah yang berafiliasi dengan pemerintah Indonesia. Hanya ada beberapa pesantren yang menolak sistem pendidikan modern. Pesantren Al-Is'af menolak sistem pendidikan sekolah dan telah mempertahankan keberlanjutan pendidikan tradisional dalam pembelajaran dan pengajaran pengetahuan Islam. Penolakan itu memunculkan upaya pesantren dalam memperkuat pengajaran buku teks Islam klasik (kitab kuning) dengan metode sorogan dan bandongan. Beberapa buku teks telah mengajarkan aturan pembelajaran santri. Ada banyak aturan, norma, dan kepercayaan yang menghasilkan budaya belajar di pesantren.

Kata Kunci: Penolakan, Pondok Pesantren, Modernisasi Pendidikan, Budaya Belajar. 


\section{A. Introduction}

Islamic boarding schools are traditional educational institutions that bear and grow together with the arrival of Islam to Java. Thus, the pesantren constitutes the oldest educational institutions and native (indegenous) in Indonesia. As an institution of traditional islamic education, ${ }^{1}$ it is suspected to have a close relationship with the tradition in the Hindu-Buddhist pre-Islamic. ${ }^{2}$ In this context, Islamic boarding schools are synonymous with the meaning of islam and meaning of authenticity of Indonesia (indegenus), and forward and islamize the educational institutions that already exist. ${ }^{3}$

At the beginning of its birth, the boarding schools - as an institution of traditional education, only taught the classical islamic sciences. Boarding school is what is then known as pesantren salaf. But since the end of the $19^{\text {th }}$ century, pesantren as an traditional educational institution get challenge, that is, when in the 1870 s, the Dutch Colonial government introduced a system of school education, namely with the establishment of the people's school (volkscholen) or also called the school of the village (nagari) with a study period of 3 years with students of about 16.606 people. ${ }^{4}$ In 1871, there were approximately 263 elementary school of such a kind and ahead of 1892 increased to 515 the school with a student population of about 52.685 people.

The establishment of these schools, received an unsatisfactory from among the people of Indonesia at that time. This is characterized by a high dropout rate and the quality of teaching

1 Arief Subhan, Lembaga Pendidikan Islam Indonesia Abad Ke-20: Pergumulan antara Modernisasi dan Identitas (Jakarta: Kencana Prenada Media, 2012), 29. See also Yanwar Pribadi, "Religious Networks in Madura Pesantren, Nahdlatul Ulama, and Kiai as the Core of Santri Culture", al-Jami'ah 51, no. 1 (2013): 4.

2 Samsul Nizar, Sejarah Sosial dan Dinamika Intelektual Pendidikan Islam di Nusantara (Jakarta: Kencana Prenada Media Group, 2013), 113. See also Hanun Asrohah, “The Dynamics of Pesantren", Journal of Indonesian Islam 5, no. 1 (2015): 41.

3 Nurcholish Madjid, Bilik-bilik Pesantren: Sebuah Potret Perjalanan (Jakarta: Paramadina 1997), 3.

4 Azyumardi Azra, Pendidikan Islam: Tradisi dan Modernisasi di Tengah Tantangan Melenium III (Jakarta: Kencana Prenada Media Group, 2012), 117. 
is very low. Resistance to schools created by Netherlands was very strong in the people of Indonesia, especially in Java, because they considered these schools as part of the efforts of the Dutch colonial government to make their children like the Dutch.

The difficult challenge also came from the Muslim reformers. In the twentieth century, the reformers established institutions of Islamic education as a modern answer to the challenges of colonialism and christianization. At that time there were two educational institutions of modern Islam in Indonesia. First, they established public schools, but they inserted the knowledge of Islam. School building with the type above, for example done by Syeikh Abdullah Ahmad from Padang Panjang, who had the Iron Bridge Mosque, but he was more interested in managing the modern schools. On August 23, 1915, he established the Adabiyab School ${ }^{5}$ by using four Dutch teachers and two Indonesian teachers which has a certificate of teaching in HIS. In 1916, the Dutch Government recognized this school as the first HIS which was established by an Islamic organization, which then in the next year it got a full subsidy from the government.

Second, those who established the modern schools, which are limited to adopt the substance and methodology of modern education. ${ }^{6}$ In this category, Zainuddin Labai al-Yunusi founded the Madrasah Diniyah by applying the model of modern education, in whivh stratification was used, the curriculum was a blend of Islamic knowledge and general science, especially historical science and earth science. Likewise, the organization of Sumatra Tawalib established modern schools in Padang Panjang, Parabek, Batu Sangkar, Maninjau, Bukit Tinggi, etc. In the same period, the school was also established by the Jamiat Khair and al-Irsyad.

5 Arief Subhan, Lembaga Pendidikaan, 107.

6 Syamsuddin Arif, Jaringan Pesantren di Sulawesi (1928-2005) (Jakarta: Badan Litbang dan Diklat Departemen Agama RI, 2008), 5. 
The response of the Islamic boarding school against the schools and Islamic schools established by the reformers of Islam was the "resisting while copying". On one hand, boarding schools rejected assumptions of the reformers and looked at it as a serious threat against the Islamic boarding schools, but also within certain limits to follow and imitate the steps of the reformers, in order to survive. $^{7}$

Therefore, the majority of Islamic boarding schools did the adjustment steps that they believed would provide benefits for the students, and support the sustainability and survival of the Islamic boarding schools, such as the system of classes (classical) and a planned curriculum, clear and regular. ${ }^{8}$ With the development of the school education system, they rejected the assumptions and understanding of the reformers' religion, but for certain limitation, followed the steps of the modernists in order to survive. Therefore, the Islamic boarding schools did adapted steps that they considered to support the continuity of the Islamic boarding schools, and was also beneficial for the development of education as a system of classes, the curriculum was clear and classical systems. ${ }^{9}$

Meanwhile, some small Islamic boarding schools shows a rejection of the system of school education. ${ }^{10}$ These Islamic boarding schools only carries out traditional learning that are being carried out with the teaching of Islamic classic books without being interfered with profane sciences. ${ }^{11}$ Their choice is caused by the strength of their belief that demanding science which they call the science of religion is an ain obligatory, namely the obligation

7 Karel A. Steenberik, Pesantren, Madrasah, Sekolah: Pendidikan Islam dalam Kurun Moderen (Jakarta: LP3ES,1994), 65.

8 Steenberik, 67.

9 Azymardi Azra, Pendidikan Islam, 105.

10 Ronald Lukens-Bull, "Madrasaby Any Other Name Pondok Pesantren and Islamic Schools in Indonesia and Larger Southeast Asian Region", Journal of Indonesian Islam 4, no. 1 (2010): 11.

11 Departemen Agama RI, Pondok Pesantren dan Madrasah Diniyab: Pertumbuban dan Perkembangannya (Jakarta: Dirjen Bagais, 2003), 29. 
for every individual Muslim. The science that had beed stated ain is the science of Tauhid and Fiqh, because with both of them, a Muslim will be able to know the essence of God, the oneness and His attributes. In addition, with the science of Fiqh one can know the ins and outs of the worship to Allah, such as prayer, fasting, zakat and others. ${ }^{12}$

This paper wants to examine: (1) the reasons for the rejection of traditional Islamic boarding school towards the modernisation of education; (2) efforts to strengthen the education of traditional Islamic boarding school; (3) the Implications of the sociological and political rejection of traditional Islamic boarding school towards the modernisation of education.

I choose Al-Is'af Islamic Boarding School as the object of this paper because of some following reasons: (1) this Islamic boarding school is well known as traditional Islamic boarding school that has been widely known in Madurese society, and teaches classical books intensively; (2) this Islamic boarding school plays important role in discussing events about problems of Fiqh (babts al-masa'it) at regional level or national level, as held by Nahdlatul Ulama; (3) this Islamic boarding school has been shown as one of the Islamic boarding schools that is still liked by traditional society in Madura (1.000 santri), in the middle of the competition of big Islamic boarding schools in Sumenep, such as An-Nuqayah Islamic Boarding School, Guluk-Guluk, Sumenep (consists of 7.000 santri), and Al-Amin Islamic Boarding School (with 5.000 santr). ${ }^{13}$

Theoritical significance of this article is to deny the signalement from some experts that if Islamic boarding schools do not modernize their education systems and reject school education system and madrasah, so Islamic boarding schools will be lack of devotee and can cause the dissolution of the Islamic boarding schools.

12 M. Dian Nafi', et al., Praksis Pembelajaran Pesantren (Yogyakarta: LKiS,2007),78.

13 Al-Is'af Islamic Boarding School is only $7 \mathrm{~km}$ from An-Nuqayah Islamic Boarding School, the biggest Islamic boarding school in Sumenep and the most students. 


\section{B. Discussion}

\section{Government Policy Related to Islamic Boarding School Modernization}

The modernization of islamic boarding school education, is believed as one of the ways done by Islamic boarding school to keep exist in the middle of competitions with modern educational institutions that offer secular education through school education system that was built intentionally by the government of Dutch Colony. The modernization of Islamic boarding school education system was begun at the Dutch Colonial era, in which at that time, they introduced school education system, to enlarge the chances for indigenous people, to get modern education. The first islamic boarding school that modernized its education system was Manbaul Ulum Islamic Boarding School of Surakarta. This Islamic boarding school was built by Susuhunan Pakuwibowo in 1996 in which it became the pioneer of the entrance of general education in Islamic boarding school. According to the report of the inspection of Dutch education, in that year, Manbaul Ulum Islamic Boarding School had inserted reading subject (with Latin), Algebra, and Arithmetics in their education curriculum. ${ }^{14}$

The step taken by Manbaul Ulum Islamic Boarding School Surakarta, was also followed by Tebuireng Islamic Boarding School, Jombang, in 1935, a madrasah with a modern system was opened in which it was called as Madrasah Nizamiyah, it was the result of K.H.A. Wahid Hasyim's work that was implementing system and subjects which had been never known in the Islamic boarding school world as a whole, and there was no one who was brave to create it as one of the part of Islamic boarding school education. In the madrasah, besides Islamic education subjects and Arabic, other general education subjects such as Dutch language and English language were also thought there. Both of them were considered

14 Azra, Pesantren, xv. 
baram in Islamic boarding school athmosphere in that time. ${ }^{15}$

The existence of general knowledge subjects in Tebuireng Islamic Boarding School, was very popular in Java and Madura, they inspired other Islamic boarding schools to do the same step. From that time until now, many Islamic boarding schools that previously only learnt about traditional Islamic books, also carried out the madrasah and school education system by following the government curriculum. ${ }^{16}$

The response of the world of Islamic boarding schools to the modernization, can be seen monumentally from the existanceof Gontor Modern Islamic Boarding School that was founded by three brothers in 1926, they were Kyai Ahmad Sahal, Kyai Zainuddin Fanani, and Kyai Zarkasyi. This Islamic boarding school offered modern education system in which at the first time they only held elementary school or ibtidaiyah, and then in 1936, this Islamic boarding school built junior high school and senior high school. These two education levels were then united and named as Kulliyatul Muallimin Al-Islamiyah (KMI). The curriculum of KMI consisted of Islamic subjects, general subjects, and foreign languages subjects (Arabic and English), at that time there was no pressure from other Islamic boarding schools yet. The teaching and learning process in this Islamic boarding school focused on the practice of Arabic and English language in their college environment as daily languages. ${ }^{17}$

After the independence era, Islamic boarding schools got another hard challenge, when there was an expansion of public school and modern madrasah. The response of Islamic boarding school toward the two kinds of education institution were revising their curriculum and inputted a lot of subjects to their education systems, and opening the institution and education facilities for

15 Aceh, Sejarah, 153.

16 Steenbrink, Pesantren, 120.

17 Yasmadi, Modernisasi. 
general education interests. ${ }^{18}$

At that time, there were a lot of Islamic boarding schools that kept maintaining their traditional education, and also built some formal madrasah which stayed under Ministry of Religious Affairs. When they opened formal schools, the learning process in those schools must employ the curriculum that was suitable with the applied law and regulation.

The change on Islamic boarding school education by building madrasab was continued. After Indonesia gained their independece, Islamic boarding school underwent some changes in their education systems, one of the striking changes was the release of joint decree letter by three ministers, they were Ministry of Religious Affairs, Ministry of Education and Culture, and Ministry of Home Affairs no. $6 / 1975$, no. $037 / \mathrm{U} / 1975$, and no. 36/1975 about the quality enhancement of education. The joint decree letter gave more strategic positions to the madrasah, they were: (a) the certificate from madrasah has the same value to public school; (b) their alumnus are able to continue their study to the public school in the next level; (c) the students from madrasah can move to the public school with the same level. After all, it could cause the percentage of religious subjects decrease for about 30\% while general subjects were increasing for about $70 \%$.

The more basic change happened since national education regulation number 2 year 1989 was applied, where madrasah must engage general subjects with the same portion as public schools do, which means the curriculum of madrasah is $100 \%$ similar to the public school curriculum. To preserve Islamic boarding school as educational institution that produce Islamic scholars, many Islamic boarding schools implemented madrasab education which was suitable with the curriculum implemented by public schools (such as Mathematics, Social Science, Natural Science, Indonesian Language,

18 Azra, "Pesantren", xviii. 
English Language, Art, Sport, and Craft) in the morning, while in the noon, afternoon and at night, they kept learning about Islamic subjects.

However, not all Islamic boarding school are welcome to the modernization of education by implementing madrasab education and school in their education systems. There are some Islamic boarding schools that refuse to modernize their education systems and continue their traditional educations. In the implementing their education systems, they just want to study about Islamic subjects by using classical books as references. The teaching methods that are apllied are bandongan, sorogan, and discussions (musyawarah).

Although those Islamic boarding schools still keep their traditional education, they are still exist and are able to attract attention of Muslim society very significantly because those Islamic boarding schools are still liked enough and they do not get a decadence.

\section{Pesantren Al-Is'af and Its Response to Educational Modernization}

In 1950 K.H. Mohammad Rais Ibrahim built a langgar in Kalabaan, Guluk-Guluk Village. The langgar was used by Kyai Rais as a place to whorship, and to learn about Al-Qur'an as well. Santri at that time, came from the village (santri kalong) and there were no santri who stayed at the langgar. Therefore, in that time, there was only one subject to be learnt, that is Al-Qur'an, where the santri recited Al-Qur'an in front of their Kyai, and Kyai corrected their reciting.

After Kyai Rais passed away, the leadership of education in langgar was continued by his son K.H.M. Habibullah Rais. In his leadership, the nickname of Habibullah Rais, langgar education gradually became an Islamic boarding school and in the next time, it became to be one of the islamic boarding schools which was highly rated by society until now. 
In the beginning era, this Islamic boarding school had only two santri whom were hardly studied about Arabic. With high seriousness and patience, Kyai Habib succeeded in making those two students to master Islamic classical books, as the result, many members of society decided to put their children to that Islamic boarding school. The mastery of two language tools ( $N a h w$ and Sarf) gave an images to the society about the specialization of Al-Is'af Islamic Boarding School that very concerned on those two subjects, which are in the reality, they have the proficiency on these fields. Those cases were related to the Kyai Habib's view that two fields should be mastered first, since it can be basic requirement to deepen classical Islamic books.

This Islamic boarding school was well known as traditional Islamic boarding school by the society, with the numbers of the students for about 1.150.000 (one million one hundred and fifty thousand) students. All of students are generally from the families that economically constitute moderate society.

Based on their regions, Kalabaan students were from villages in one district (Guluk-Guluk) and the closest districts (Ganding, Lenteng, Paragaan). Meanwhile, there were some students who came from relatively longer districts, but they were still in Sumenep Regency (such as: Gapora, Batang-Batang, Kalianget, Kangean, Sapeken, and others). Besides that, a few students were from Jawa Timur like Banyuwangi, Jember, and Bondowoso.

If we see from their original regions, it can be described that the figure of leader of Al-Is'af Islamic Boarding School spreaded in villages in Sumenep Regency, whether they are near or far, and also those were from outside Sumenep in Madura Island until eastern of Jawa Timur.

Furthermore, Kyai Habib wanted that the direction and the purpose of his Islamic boarding school could not be changed forever although they had passed away, therefore he must write that message to their heritage to whomever would be his successors in the next 
time. His message was written on a wooden board hanged in front of a mushalla's room near the living room as follow: "Pesantren areya tak olle eobah sampe billah baib" (this Islamic boarding school can not be changed forever). These message was a heritage and attention to his children not to change the direction, and the main aim and education system of Al-Is'af Islamic Boarding School.

The rejection of Al-Is'af Islamic Boarding School to the modern education system was caused by the desires and strong principle from the leader of this Islamic boarding school. Kyai was the only autoritative figure in this Islamic boarding school, whom really determined the direction and the characteristics of the education of this Islamic boarding school. However, the other members such as the representative, and tutors of this Islamic boarding school also followed the policy, they were afraid to take other ways contrasted with his top leader. The establisment foundation of Al-Is'af Islamic Boarding School kept with its traditional education, which was very influenced by the world view about science, world and human's obligations in this life, it was mainly about science field that must be studied related to duty and function of human in undergoing this life, it is about worshiping to Allah. The followings are the statements given by the leader of Al-Is'af Islamic Boarding School about his decision in defense of the traditional education in his Islamic boarding school.

"I keep this traditional education and will not change the madrasab or school education that are under the government, the first reason is I want to preserve the Islamic subjects from scarcity. I remember what al-Ghazali ever said, he stated that at al-Ghazali's era, the Islamic subjects were more faded. People were not interested in studying the religious sciences, therefore al-Ghazali needed to reborn such religious subjects. According to his view, in my opinion, in this era, it is very needed to preserve religious subjects to face some challenges in front of the islamic society. I don't operate madrasah that followed the government rules, because someone should study islamic subjects wholeheartedly. I don't want to do other education system except Islamic education because I can not teach it, and 
if this Islamic boarding school is given to the people who do not follow the system which I made before, this Islamic boarding school will be cer kalacer (broken). Therefore, I truly concern to keep this education system in which it has been done in this islamic boarding school in early beginning." 19

From the statements above, it can be concluded that the rejection made by al-Is'af Islamic Boarding School is one effort that is done by the leader in giving response to the proliferation school education held by most of Islamic boarding schools. Even, there are two big islamic boarding schools that ever implemented formal education. Ideologically and geneologically, the reasons of the rejection given by the leader of Islamic boarding school are mostly influenced by al-Ghazaly's statement which told that the interests of Muslims society in learning religious subjects has been more faded, so that it is very important to reborn those religious subjects.

The views and belief above are clearly seen from the rejection of al-Is'af Islamic Boarding School to the modern education, their traditional education are very determined by the leader's wish and his family when they are still holding the highest position until now. They very concern to the continuity of the traditional education system. Kyais view as the leader takes the most part in determining the direction and the purpose of the education in Islamic boarding school, considering that the high authority Kyai has in his Islamic boarding school is absolute in which it is derived from his high charisma through his deepest knowledge and his great personality.

\section{The Streghtening of Education System of Pesantren Al- Is'af: Paedagogical Implication}

Al-Is'af Islamic Boarding School's rejection to the modern education system is followed by some efforts that are taken in streghtening the traditional education system, which resulted culture

19 Mohammad Habibullah Rais, Interview, April 23, 2015. 
of the study that can guarantee the continuity of their characteristic as traditional Islamic boarding school.

The streghtening of education system which is done by this Islamic boarding school could be seen from three education aspects, namely: (a) the streghtening of learning process towards classical Islamic books; (b) the streghtening of the methods; (c) and the streghthening of the learning evaluation.

The streghthening of learning process is executed by intensifying the studies of classical Islamic books especially in Nahw and Sharf field and Figh. It is done by considering the importance of those subjects in understanding the classical Islamic books. The leader of Al-Is'af Islamic Boarding School judges fardu 'ain as students to learn them. The base of this fardu 'ain judgement is Ushul Figh principle, it is "Ma la yutimm al-wajib illa bibi fabuwa wajib" (Something/attitude which can create an obligation perfect, so the law of them is obligatory). Because learning religious subjects is an obligation, therefore the tools to learn about it—learn about Nahw and Sharf - is an obligation too. The stressing on Nahw and Sharf subjects in Al-Is'af Islamic Boarding School is focused on the use of Alfiyah books, which consists of 1.000 verses. ${ }^{20}$

Another field that has the biggest portion in the second place is Fiqh subjects (Islamic jurrisprudent). The study of Fiqh in AlIs'af Islamic Boarding School began since the students came in and studied there. It began in the adna level, the study of Fiqh was given to the students by using Madurese language books, and written in Arabic composed by the leader of this Islamic boarding school, K.H. Habibullah Rais. Those Figh books were such as Umm alIbadah and Safinah as-Salah. These books studied about the principles of worship in basic level, such as book of purification, book of prayer, and book of fasting. The study of fiqh by using Arabic is given to wusta (high) level by utilizing the books such: at-Taqrib, Fath al-Qarib al-Mujib, and Tuhfah ath-Thullab. The study of these books

20 Totok Tijani, Interview, September 24, 2015. 
have been enough for the students to understand the principles of Islamic laws. The other subjects that are also learnt besides Nahw and Figh are Tafsir, Hadith, Akhlaq/Tasawuf, Sharf, Bayan, Ma'ani, and Badi', those are learn in Al-Is'af Islamic Boarding School as additional studies to expand and enrich the treasure of students' intellectuality.

Whereas the teaching learning methods that were applied in this Islamic boarding school are divided into two. The first, the books recitation were lead by the leader and other Kiai (his son in law and his son) used the traditional methods, such as bandongan, sorogan, and group discussion. By using bandongan method, Kyai reads the book first and explains the meaning of it word by word or sentence by sentence from books that has been explained, and at the same time the students give note based on Kyai's explanations in the edge of their books. While in sorogan, emphasizes more on the students' activity by obligating them to read, translate, and report their memorization to their Kyai.

The second, is babts al-masa'il method (problem based learning method). This method is done in two forums of study, they are the following: (a) babts al-masa'il is applied by the students under the teachers' guidance; (b) bahts al-masa'il, is done by the teaches under Kyai's guidance as the leader of Islamic boarding school directly. The first forum is held in the classroom, it is for the students outside their academic subjects guided by senior teachers, this method is implemented as media to the student to train themselves in mastering the principles of islamic law and argue to opinions being proposed. While in the second forum, each teachers hold discussion about some problems in Fiqh (Islamic law) under Kyai's guidance. The topic of discussion in this discussion forum was given a month earlier so that the students can prepare and strengthen their opinions and arguments. The answers given should be based on the books compiled by scholars who have been recognized and admitted their expertise. 
The streghtening process and learning models above are followed by learning evaluation. This evaluation is done by the teacher in each catur wulan. This evaluation is used to know how far is the students' understanding to the subjects that have been taught. In addition, there is evaluation in each year to determine the students' grade promotion.

This evaluation is executed by selected team that consists of the teachers except those who have taught in the classroom. This evaluation is accomplished in Islamic boarding school's hall with the questions from the examiners. The type of this evaluation is written form which is held in hall. All of the students in the same level do the written test. The test maker, the examiner and the supervisor on that test are pointed by family's assembly directly. They consists of teachers and caretaker besides the teachers who have schedule in the class. So, in the promotion grade, the classroom teachers are not involved, but it is totally handled by special committee. They are vowed by the leader or family's forum to do, to correct, and to score objectively. The graduation on this promotion grade test is determined by certain passing score that must be achieved by the students, they are the students who get half of the total score.

After the student finished written test, they should do voiced test that was done at school yard in the middle of Islamic boarding school's environment. In this test, they were called one by one to come forward and stand up at the open stage, while the examiners were asking some questions that should be answered by the students. Through this system, there was possibilty to all students, teachers and caretakers were able to know the abilities of the students. In accordance with the questions from the examiners, the students answered by using microphone, in which the examiners gave final score as the consideration in determining the promotion grade of the students.

Thus, the evaluation in Al-Is'af Islamic Boarding School have been executed by using the evaluation principles of modern 
education, it is matched with what have been applied by public schools, therefore in this context, there is a fact that Al-Is'af Islamic Boarding School have known well about the quality assurance system of the students' learning result, by using evaluation system and evaluation which are accountable, measurable, institutional, objective, and regular periodically.

\section{Values, Learning Attitude, and Social Identity}

The education system of Al-Is'af Islamic Boarding School is based, driven, and guided by the values of life which is based on the basic teachings of Islam. This basic teaching is walking along with contextual structure or social reality surrounding in life. The result of combining the two is what form the world view and outlook on life is what set educational goals to be achieved and the choice of means that will be pursued. Therefore, a person's outlook on life which is always changing and evolving in accordance with the changes and development of social realities faced. ${ }^{21}$

Mastuhu states that the education system in pesantren is based on the intense combination between the basic tenets of the religion which is believed to have the value of absolute truth and social reality that has value of relative truth. As explained in theocentric philosophy, religious values with the absolute truth has a higher truth above relative truth, and the truth of relative religion value should not be opposed to the value of absolute truth.

Thus, the students in Al-Is'af Islamic Boarding School in running the learning process is driven by the values of Islam written in the learning resources, in the form of classical Islamic books which consistently taught by Kyai and religious teachers (ustady) at schools. That value serves as the source of inspiration and driving force for their success in learning. The study books, which become the source of value for students in carrying out the learning process, are al-Ghazali's Ibya' 'Ulum ad-Din, Burhanuddin az-Zarnuji's Ta'lim al-Muta'allim, and K.H. Mohammad Habibullah's Minbaj al-Irsyad.

21 Mastuhu, Dinamika Pendidikan Pesantren (Jakarta: INIS, 1990), 34. 
The values, that drive the students of Al-Is'af Islamic Boarding School in implementing the learning process, are: the first, learning is as an effort to draw closer to God and it is not justified that students learn with mundane objectives. ${ }^{22}$ In this context, learning should be based on sincerity in gaining the pleasure of Allah. With this value, the students' learning behavior are followed with the worship practice in closer to Allah. In the classroom, they start their learning activities by reading supplication (doa) and qikir as a means to achieve success in learning. Likewise, when the learning activity is accomplished, kyai/ustadz ends it by doa recitation. Learning should prioritize aspects of rubaniyyah (asceticism). In addition, students enrich themselves with reading wird, zikir, and bizil which are performed before or after shalat that are believed to support the success of their study in pesantren.

Second, the study must be accompanied by continuing to give high respect to the teachers. Santri are prohibited to argue against the explanations given by ustadzas way to hope their ustadz's contentment to make the knowledge they gained useful and helpful. This value results to santri's behavior to respect, abide and subject totality all orders of kyai and ustadz teaching them. They deny what is explained by kyai. They do not dare to ask or refute the explanation of kyai. In the process of learning the books, kyai explains the material and content of the book, students listen, note the explanation under the sentences which are described by kyai. Question and answer session is not found in this teaching and learning models. Such kind of this learning model is called bandongan.

Third, santri should prioritize studying Imu Taubid and Ilmu Ibadah to Allah, because those knowledge are fardu 'ain (personally obliged) to learn. They should be sincere and concentration in carrying out the process of learning. That value produces students'

22 The real result of studying knowledge is to get closer to Allah, the lord of the universe, and to connect ourselves to the high angels and to gather with the spirit world. All that is the majesty and reverence instinctively. Al-Ghazali, Ibya' 'Ulum ad-Din (Beirut: Dar al- Fikr, n.y.), Volume I, 10. 
learning behavior which focuses on deepening the books that discuss the beliefs of Islamic law and Tasawnf. They do not want to learn the mundane knowledge. They believe that only religious knowledge is important to learn while other knowledge is not really important to learn in their life. ${ }^{23}$ The life in Al-Is'af Islamic Boarding School, students show to be active in the study of the classical books, especially Nahwu and Fiqh.

Fourth, learning should be coupled with modesty. ${ }^{24}$ This value is one of the values of pesantren which is a continuation of a tribute to teachers. Humility they show when they are facing the kyai. In front of their kyai, they sit cross-legged with head bowed and arms crossed put in front of their body. Their humble behavior is also shown to their ustadz. The behavior of simplicity, they show it to their simple daily dietary menu such as rice, tempe, tabu, which is occasionally interspersed with a piece of sea fish. Likewise, the simplicity is also visible on their clothing, such as a cheap white shirt and sarung. Their simplicity is also visible on the availability of perfunctory facilities and learning tools. Classroom as a place of learning is not equipped by chairs and tables. Pupils sit in crosslegged on the floor, while the ustadz sit on the chair in the front of the class.

23 This value is derived from the explanation of K.H. Habibullahi as follows: "knowledge is divided into three kinds, namely fardu 'ain and fardu kifayah knowledge, sunnab knowledge and haram (forbidden) knowledge. The knowledge which are categorized as fardu 'ain knowledge are the knowledge which studied ibadah fardu 'ain. The knowledge to enforce the religion is included into fardu kifayah. The knowledge are syari'ab knowledge and alat knowledge such as Nahw and Sharf. Likewise, to deepen the knowledge which is needed for the benefit of living in the world, such as medical science and mathematical science is included as sunnah, because it is rarely happened in society. Natural science, political science, psychological science, earth science, historical science, and mathematic are needed for faraid. Meanwhile, deepening the sciences which are included fardu kifayab is sunnah. Let you explore and practice the science or knowledge which its law is fardu 'ain. Mohammad Habibullah, Minhaj al-Irsyad (Sumenep: n.n, n.y.), 35.

24 Deriving from the teaching of al-Ghazali, which quotes a hadith of Prophet Muhammad PBUH, as follow: Narrated to us by Qutaibah, narrated to us by Abdul Aziz bin Muhammad from al-A'la bin Abdurrahman from his father from Abu Hurairah that Prophet Muhammad PBUH said that: "The charity will not reduce property. One who forgives will be increasingly getting more precious. And one who is tawadu' (in humility) because of Allah but Allah will elevate him." Abu Hamid Muhammad bin Muhammad al-Ghazali, Ihya' 'Ulum ad-Din (Beirut: Dar al- Fikr, n.y.), Volume III, 333. 
Fifth, students have to undergo the character of simplicity prioritizing ascetic nature (asceticism) ${ }^{25}$ This value generates simple attitudes and behaviors of students in food, drinks, clothing and beds (dormitory at boarding school). Ascetic behavior demonstrated by the activity that promotes rubiyah (mysticism) aspect in the learning process of students, such as fasting, prayer nights, accustoming long qikir, wirid, and bizb. Pupils believe that those mystical activities can make students easier to achieve the success of learning. The values that generate behavior of students in their learning activities are interrelated shaping organizational culture of Al-Is'af Islamic Boarding School, which is defined. According to Schein, as quoted as "the collective sum of beliefs, values, meanings, and that assumptions are shared by social group and that help to shape their ways in the which they respond to each other and to their external environment". ${ }^{26}$

Based on the above definition, it can be affirmed that the culture of Al-Is'af Islamic Boarding School is an integral value of beliefs, and behaviors that are created by the founder of pesantren which are communicated and shared by most members of pesantren (kyai, religious teachers, and students) in the form of conviction and behavior becoming as culture of pesantren which then creates a group identity of students of pesantren salaf as a social group in society. Their group identity is as a part of each personal concept coming from the knowledge, values, and emotional from the membership of the group. This social identity distinguishes the students of pesantren salaf and other social groups. They distinguish themselves

25 Al-Ghazali cites a hadith of Prophet Muhammad PBUH as follow: Narrated to us by Abu 'Ubaidah bin Abu As Safar, narrated to us by Syihab bin 'Abbad, narrated to us by Khalid bin 'Amru al-Qurasyi from Sufyan ats-Tsauri from Abu Hazim from Sahl bin Sa'd as-Sa'idi, he said: A man came to Prophet Muhammad PBUH while saying, "O Messenger of Allah, show me a deed that if I do then Allah and all humans will love me." The Prophet Muhammad PBUH said, "Be zubud in world affairs, undoubtedly, you will be loved by Allah. Be zubud to what other people have, then they will surely love you." Abu Hamid Muhammad bin Muhammad al-Ghazali, Ibya' 'Ulum ad-Din (Beirut: Dar al- Fikr, n.y.), Volume III, 345.

26 Pepen Supendi, "Karateristik Kepemimpinan Kiai dalam Memelihara Budaya Organisasi dan Kontribusinya terhadap Mutu Pendidikan Pesantren: a Study at Pesantren Al-Ashriyyah Nurul Iman Islamic Boarding Schools Bogor and Pesantren Amanah Muhammadiyah Tasikmalaya", accessed at www.uinsgd.ac.id, on November 3, 2016. 
with students of modern pesantren or social group of a not santri out of them.

With their social identity, emotionally they feel that they have the advantages compared to outer social groups. They believe that a Muslim should deepen Islamic knowledge from the original source, namely the classical books. Their capabilities and expertise in reviewing the Arabic classical books give perception of themselves as a community of who is the best in understanding Islam.

On several occasions, they give a negative assessment to the students / Muslims who do not have the ability to understand Islam through the classical books. Even, they underestimate the knowledge which they call the mundane knowledge such as mathematics, natural sciences, social sciences and others.

\section{Conclusion}

Al-Is'af Islamic Boarding School rejects school education system as held by the government, this rejection is done by defending their direction, purpose, characteristic and their traditional curriculum.

The decision of Al-Is'af Islamic Boarding School in defending their traditional education system can not be replaced by the view and principle of Islamic boarding school leader which believes that studying Islamic subjects are obligated and should be based on the original sources, they are classical books and arabic books. This opinion is in line with al-Ghazali's opinion in which he states that it ia a must for moslems to study religious sciences. While studying other subjects is wajib kifayah, sunnah, mubah, and even some of them are forbidden.

The defense of Al-Is'af Islamic Boarding School to their traditional education is followed by some changes in their learning methods, they create a learning process that is substantially not out of the traditional education, however, metodologically it has undergone some changes and innovations. In other words, Al- 
Is'af Islamic Boarding School defends their traditional education, practising the principles that are well known in modern education (school), such as education level, the use of learning methods and evaluation system that is objective, regular, and institutional.

As a part of national education system, traditional Islamic boarding school (pesantren salaf), that also contribute in educating this nation should get the serious attention from government and society. Al-Is'af Islamic Boarding School as traditional (salaf) Islamic boarding school has done some changes and innovations, so that it can reconstruct their education system and produce professional graduation fitted to the education goals that want to achieve.

Therefore, Islamic boarding school is very suitable to be put in the same position with other education institutions, because they also play important role in giving the light to the children at this nation, at least in the framework of keeping national moral through education system that still focuses on character building.

Besides, it is very ideal if someday traditional Islamic boarding school does not only play as "goal keeper" to the continuity of Islamic science, but also give them enough room to the students to study other subjects that can open their insight of mind especially about methodology. Beside that, traditional Islamic boarding school can give life skill to prepare them to enter the real life in society. The effort above is at least to give them bright insight, that today they live in the world that have been changed and will always develop, by which it demand the readiness to face them in each competence and skills that are needed through education that are adaptive, competitive, and futuristic without reducing even more losing the traditional education and values, ideology, and intellectual heritage of the past Islamic scholars (as-salaf ash-shalih). 


\section{REFERENCES}

Arif, Syamsuddin. Jaringan Pesantren di Sulawesi (1928-2005). Jakarta: Badan Litbang dan Diklat Departemen Agama RI, 2008.

Asrohah, Hanun. "The Dynamics of Pesantren", Journal of Indonesian Islam 5, no. 1 (2015).

Azra, Azyumardi. Pendidikan Islam: Tradisi dan Modernisasi di Tengah Tantangan Melenium III. Jakarta: Kencana Prenada Media Group, 2012.

Departemen Agama RI. Pondok Pesantren dan Madrasah Diniyah: Pertumbuban dan Perkembangannya. Jakarta: Dirjen Bagais, 2003.

al-Ghazali, Abu Hamid Muhammad bin Muhammad. Ibya' 'Ulum ad-Din. Beirut: Dar al- Fikr, n.y.

Habibullah, Mohammad. Minhaj al-Irsyad. Sumenep: n.n, n.y.

Lukens-Bull, Ronald. "Madrasaby Any Other Name Pondok Pesantren and Islamic Schools in Indonesia and Larger Southeast Asian Region", Journal of Indonesian Islam 4, no. 1 (2010).

Madjid, Nurcholish. Bilik-bilik Pesantren: Sebuah Potret Perjalanan. Jakarta: Paramadina 1997.

Mastuhu. Dinamika Pendidikan Pesantren. Jakarta: INIS, 1990.

Nafi', M. Dian, et al. Praksis Pembelajaran Pesantren. Yogyakarta: LKiS, 2007.

Nizar, Samsul. Sejarah Sosial dan Dinamika Intelektual Pendidikan Islam di Nusantara. Jakarta: Kencana Prenada Media Group, 2013.

Pribadi, Yanwar. "Religious Networks in Madura Pesantren, Nahdlatul Ulama, and Kiai as the Core of Santri Culture", al-Jami'ah 51, no. 1 (2013).

Rais, Mohammad Habibullah. Interview, April 23, 2015.

Steenberik, Karel A. Pesantren, Madrasah, Sekolah: Pendidikan Islam 
Mohammad Muchlis Solichin

dalam Kurun Moderen. Jakarta: LP3ES,1994.

Subhan, Arief. Lembaga Pendidikan Islam Indonesia Abad Ke-20: Pergumulan antara Modernisasi dan Identitas. Jakarta: Kencana Prenada Media, 2012.

Supendi, Pepen. "Karateristik Kepemimpinan Kiai dalam Memelihara Budaya Organisasi dan Kontribusinya terhadap Mutu Pendidikan Pesantren: a Study at Pesantren AlAshriyyah Nurul Iman Islamic Boarding Schools Bogor and Pesantren Amanah Muhammadiyah Tasikmalaya", accessed at www.uinsgd.ac.id, on November 3, 2016.

Tijani, Totok. Interview, September 24, 2015. 